\title{
Amorphophalus titanum Bunga Endemik Sumatra
}

\author{
Istiqomah Widyawati, Umroh Fudolla, Wahyu Mustika Fitri \\ Mahasiswa Pendidikan Biologi, Fakultas Keguruan dan Ilmu Pendidikan \\ Universitas Sebelas Maret
}

\begin{abstract}
Amorphophalus titanum is a Sumatran endemic plant and is one of Indonesia's rare plants. Amorphophalus titanum naturally spread throughout the forests of Sumatra as a plant under the canopy (undergrowth) on calcareous soil. The purpose of this article to discuss the potential, extinction status, distribution and characteristics or morphology of Amorphophalus titanum. The roots in Amorphophallus titanum consist of tubers. The stem owned by Amorphophallus titanium is a pseudo stem composed of addicted leaf midribs. Leaf blade with a diameter of about $7 \mathrm{~m}$, leaf elliptical pine leaf, $40 \mathrm{~cm}$ long, tapered tip, if touched like a skin, the upper surface is green, rather shiny. Inflorescence on the corpse flower is a collection of small male and female flowers. The place where flowers are attached to is at the base of the cob. Spadiks is yellow and is arrouded by a reddish-purple flower sheath. Amorphophallus titanum used as an ornamental plant because of its unique shape and is able to attract the attention of many visitors.
\end{abstract}

Key words: Amorphophalus titanum, potensial, extinction status, distribution, morphology

\section{Pendahuluan}

Marga Amorpohphalus memiliki kurang lebih 200 jenis yang tersebar di Afrika Barat sampai ke Asia tropis dan Australia bagian utara. Di Indonesia terdapat 25 jenis dari jumlah keseluruhan jenis yang ada di dunia. Dari 25 jenis yang ada Indonesia, terdapat jenis-jenis yang endemik, salah satunya adalah Amorphophalus titanum. Amorphophalus titanum merupakan tumbuhan endemik Sumatra dan termasuk tumbuhan langka Indonesia. Tumbuhan ini tergolong tumbuhan langka karena bunga jantan dan bunga betina pada Amorphophalus titanum tidak masak secara bersamaan sehingga menyebabkan kesempatan untuk melakukan penyerbukan sangat kecil. Amorphophalus titanum dikenal dengan nama bunga 
bangkai karena pada saat bunga betina mekar, mengeluarkan bau bangkai. Selain dijuluki dengan nama bunga bankai, Amorphophalus titanum juga dijuluki bunga raksasa karena spadiks pada Amorphophalus titanum dapat tumbuh sampai 3 meter. Tujuan dari penulisan artikel ini adalah untuk membahas potensi, status kepunahan, persebaran serta karateristik atau morfologi dari Amorphophalus titanum.

Amorphophallus titanum merupakan tanaman dari suku Alismatales dan keluarga Araceae (talas-talasan) karena dalam perbungaannya memiliki spadix dan spatha serta akarnya yang berupa umbi (Yumazimmi, dkk., 2015). Ciri lain dari famili Araceae adalah tanaman berupa herba, batang berbentuk rimpang basah dan pendek, daunnya lanset, pangkal daun memeluk batang, berbunga majemuk bentuk bongkol yang ujungnya meruncing, buahnya bulat dengan warna yang bervariasi (Adi, 2008). Amorphophallus titanum secara alami tersebar di hutan Sumatra sebagai tumbuhan bawah kanopi pada tanah berkapur, namun tumbuhan ini ditemukan pula di tempat-tempat terbuka, hutan sekunder, pinggir jalan dan sungai, atau di tepi hutan.

\section{Pembahasan}

Amorphophalus titanum merupakan salah satu tumbuhan langka yang ada di Indonesia. Amorphophallus titanum di kategorikan ke dalam status kelangkaan 'vulnerable' oleh IUCN dan WCMC, dan di tahun 2002 dikeluarkan dari IUCN dan WCMC. Hal ini dikarenakan belum ada data komprehensif yang menjelaskan tentang populasi dan keberadaannya di alam sampai sekarang. Peraturan Pemerintah No. 7 Tahun 1999, tentang Pengawetan Jenis Tumbuhan dan Satwa, telah memasukkan Amorphophallus titanum ke dalam jenis tumbuhan yang dilindungi, terdapat dalam lampiran jenis-jenis tumbuhan dan satwa yang dilindungi (Tumbuhan - I. Palmae - No. 238. Amorphophallus titanum). Pada Peraturan Pemerintah ini Amorphophallus titanum dimasukkan dalam keluarga palem-paleman (Yuzamni dan Hetterscheid, 2014).

Masalah kelangkaan jenis ini di picu oleh berbagai faktor antara lain maraknya illegal logging, perambahan hutan untuk dijadikan perladangan, perdagangan liar burung rangkong (sebagai hewan pendistribusi biji Amorphophalus titanum). Faktor lamanya waktu yang dibutuhkan untuk beregenerasi juga menjadi penyebab kelangkaan tumbuhan ini. Berkembangnya 
mitos atau kepercayaan masyarakat setempat bahwa Amorphophalus titanum merupakan tumbuhan pemakan manusia perlu segera diluruskan. Mitos menyesatkan tersebut berdampak kepada pemusnahan Amorphophalus titanum apabila tumbuh di ladang-ladang penduduk (Yuzammi, dkk., 2015).

\begin{tabular}{|c|c|c|c|c|}
\hline No & Ancaman & $\begin{array}{l}\text { Tingkat } \\
\text { Ancaman }\end{array}$ & $\begin{array}{l}\text { Dampak } \\
\text { Utama }\end{array}$ & $\begin{array}{l}\text { Kemungkinan } \\
\text { Pengelolaan }\end{array}$ \\
\hline 1. & $\begin{array}{l}\text { Perubahan } \\
\text { lahan (land use) }\end{array}$ & tinggi & $\begin{array}{l}\text { Degradasi dan } \\
\text { kerusakan } \\
\text { sumberdaya } \\
\text { yang } \\
\text { dapat } \\
\text { mengancam } \\
\text { kepunahan jenis }\end{array}$ & - Penegakan hukum \\
\hline 2. & $\begin{array}{l}\text { Kebakaran } \\
\text { hutan }\end{array}$ & tinggi & $\begin{array}{l}\text { Degradasi } \\
\text { habitat }\end{array}$ & $\begin{array}{l}\text { - Patroli pengamanan } \\
\text { hutan } \\
\text { - Pendidikan } \\
\text { lingkungan }\end{array}$ \\
\hline 3. & $\begin{array}{l}\text { Pembabatan } \\
\text { bunga bangkai } \\
\text { yang tumbuh di } \\
\text { lahan penduduk }\end{array}$ & tinggi & $\begin{array}{l}\text { Kepunahan } \\
\text { jenis }\end{array}$ & $\begin{array}{l}\text { - Sosialisasi kepada } \\
\text { masyarakat } \\
\text { - Penyediaan alternatif } \\
\text { ekonomi } \\
\text { - Penegakan hukum }\end{array}$ \\
\hline 4. & $\begin{array}{l}\text { Perburuan } \\
\text { burung } \\
\text { rangkong }\end{array}$ & tinggi & $\begin{array}{l}\text { Degradasi } \\
\text { distribusi } \\
\text { populasi bunga } \\
\text { bangkai yang } \\
\text { apabila } \\
\text { dibiarkan } \\
\text { dapat } \\
\text { mengancam } \\
\text { kepunahan jenis }\end{array}$ & $\begin{array}{l}\text { - Melarang perburuan } \\
\text { burung rangkong } \\
\text { - Patroli pengamanan } \\
\text { hutan } \\
\text { - Pendidikan } \\
\text { lingkungan } \\
\text { - Penyediaan alternatif } \\
\text { ekonomi } \\
\text { - Penegakan hukum }\end{array}$ \\
\hline 5. & $\begin{array}{l}\text { Penjualan umbi } \\
\text { secara illegal ke } \\
\text { luar negeri }\end{array}$ & sedang & $\begin{array}{l}\text { Kepunahan } \\
\text { jenis }\end{array}$ & $\begin{array}{l}\text { - Penyediaan alternatif } \\
\text { ekonomi } \\
\text { - Penegakan hukum }\end{array}$ \\
\hline 6. & $\begin{array}{l}\text { Penggunaan } \\
\text { herbisida di } \\
\text { kebun milik } \\
\text { rakyat }\end{array}$ & tinggi & $\begin{array}{l}\text { Mematikan } \\
\text { tumbuhan dan } \\
\text { anakan }\end{array}$ & \begin{tabular}{|l} 
- Meminta penduduk \\
untuk memindahkan \\
tumbuhan ini ke \\
lokasi konservasi eks \\
situ
\end{tabular} \\
\hline
\end{tabular}


Amorpophalus titanum merupakan tanaman asli Indonesia yang endemik di Sumatra. Secara alami Amorphophalus titanum tersebar di seluruh hutan-hutan Sumatra sebagai tumbuhan bawah kanopi (undergrowth) pada tanah berkapur, namun tumbuhan ini ditemukan pula di tempat terbuka, di hutan sekunder, pinggir jalan, pinggir sungai atau di tepi hutan. (Latifah dan Purwantoro, 2015). Amorphophallus titanum (Becc.) adalah tumbuhan dengan julukan bunga bangkai yang termasuk dari suku talas-talasan (Araceae) (Mogea et al., 2001). Tumbuhan ini merupakan tumbuhan herba raksasa yang tergolong tumbuhan semusim (Yuzzami,2009).

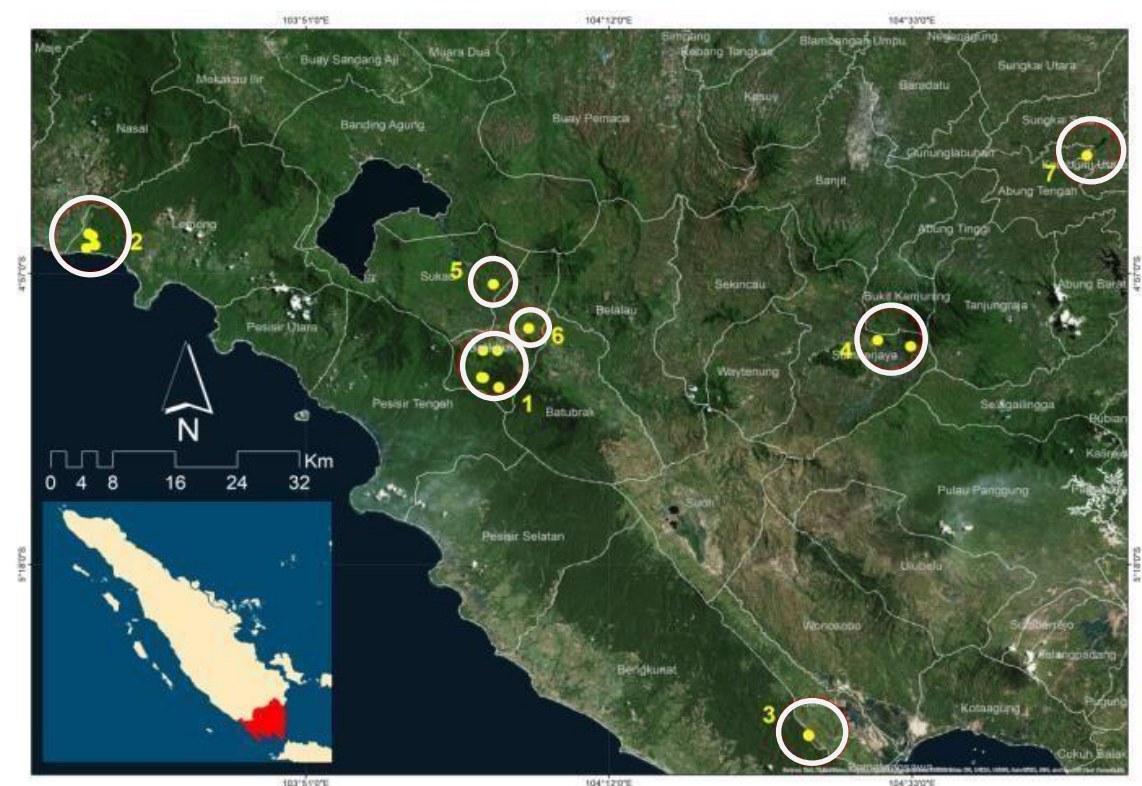

Peta sebaran A. titanum di Lampung. 1. Taman Nasional Bukit Barisan Selatan (TNBBS), Desa Kubu Perahu, Kecamatan Balik Bukit, Kabupaten Lampung Barat. 2. TNBBS, kawasan Pugung Tampak, Desa Rata Agung, Kecamatan Lemong, Kabupaten Pesisir Barat. 3. TNBBS, kawasan Sukaraja Atas, Desa Sedayu, Kecamatan Samaka, Kabupaten Tanggamus. 4. HL Sumberjaya, Desa Tribudi Syukur, Kecamatan Sumberjaya, Kabupaten Lampung Barat. 5. HL Palkiah, Register 48B, Kecamatan Sukau, Kabupaten Lampung Barat. 6. Hutan Masyarakat (HM) Desa Wates, Kecamatan Balik Bukit, Kabupaten Lampung Barat. 7. HM Desa Sungkai Selatan, Kecamatan Abung Tengah, Kabupaten Lampung Utara

Dari survei yang pernah dilakukan, diketahui bahwa A. titanum dapat tumbuh pada habitat yang cukup ekstrim antara lain pada batu gamping (limestone), tanah yang telah tererosi berat, ataupun pada ladang-ladang penduduk. Tumbuhan ini sering ditemukan pada tempat-tempat yang agak terbuka pada hutan sekunder, pada daerah yang rata maupun pada perbukitan yang curam. Jenis ini ditemukan tumbuh di habitatnya pada ketinggian 0-1.200 m dpl. (Hetterscheid \& Ittenbach, 1996). 
Menurut penelitian yang dilakukan oleh Munawaroh dan Yuzammi (2017) mengenai peta persebaran populasi Amorphophallus titanum, umumnya ditemukan dalam kawasan hutan yang kondisinya masih tergolong bagus dan belum terdegradasi berat. Sebagian besar lahan hutan telah dikonversi menjadi lahan permukiman dan perkebunan kopi. Sedangkan dalam kawasan hutan lindung, jenis ini hanya ditemukan pada dua lokasi dari lima lokasi yang dijelajahi, yaitu di HL Sumberjaya Register 45B dan HL Palakiah Register 48B. Sementara tiga lokasi lainnya di HL Lumbok Seminung Register 9B, HL Gunung Pesagi Register 43B, dan HL Bukit Subhanallah Register 44B, tidak ditemukan keberadaan A. titanum. Tutupan lahan hutan pada ketiga lokasi tersebut di atas rata-rata telah terbuka dan berganti dengan semak belukar. Degradasi lahan hutan pada kawasan tersebut sudah sangat tinggi, dan pada umumnya lahan hutan telah dikonversikan menjadi perkebunan kopi.

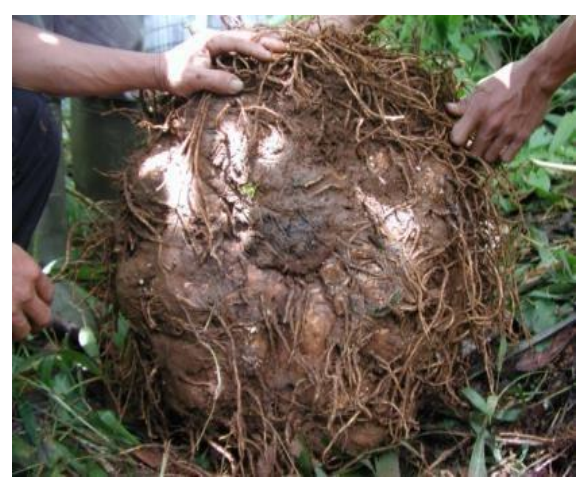

Akar pada Amorphophallus titanum berupa umbi. Umbi berbentuk membulat agak gepeng, diameter sekitar $65 \mathrm{~cm}$ dan tinggi umbi sekitar $40 \mathrm{~cm}$, berat umbi dapat mencapai $100 \mathrm{~kg}$, permukaan agak kasar dan banyak terdapat asesoris seperti calon tunas, berwarna coklat muda, tidak mempunyai tunas samping.

Batang yang dimiliki oleh Amorphophallus titanium merupakan batang semu yang tersusun oleh pelepah daun yang saling berlekatan.

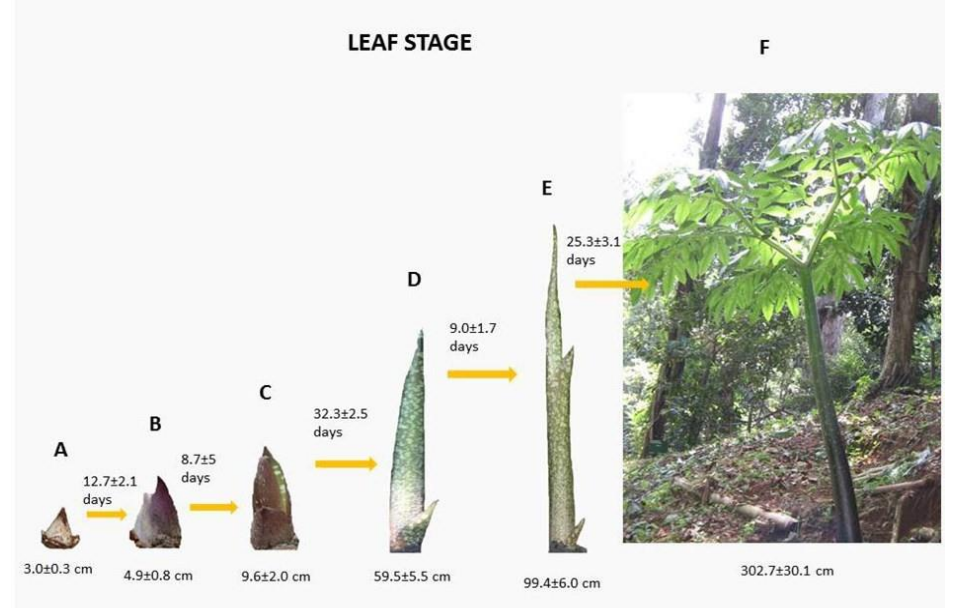

Inflorescence bud (A) and blooming flower (B) parts: cataphylls (a), spathe (b), limb (c), lower 
Helaian daun dengan diameter sekitar $7 \mathrm{~m}$, pinak daun berbentuk elips melanset, panjang mencapai $40 \mathrm{~cm}$, ujung meruncing, bila diraba seperti kulit, permukaan atas berwarna hijau, agak mengkilat. Perbungaan tunggal, tangkai bunga pendek, panjang sekitar $30-70 \mathrm{~cm}$ dan diameter sekitar $10-15 \mathrm{~cm}$, motif dan warna seperti pada tangkai daun (Yumazimmi, dkk., 2015).Tangkai daun tanaman dewasa dapat tumbuh hingga tiga meter tingginya. Terdapat bercak berupa lingkaran putih pada tangkai daun. Daun dapat bertahan selama 9 sampai 24 bulan. Daun pada tumbuhan muda hanya bertahan 6 bulan (Lobin, et.al, 2007).

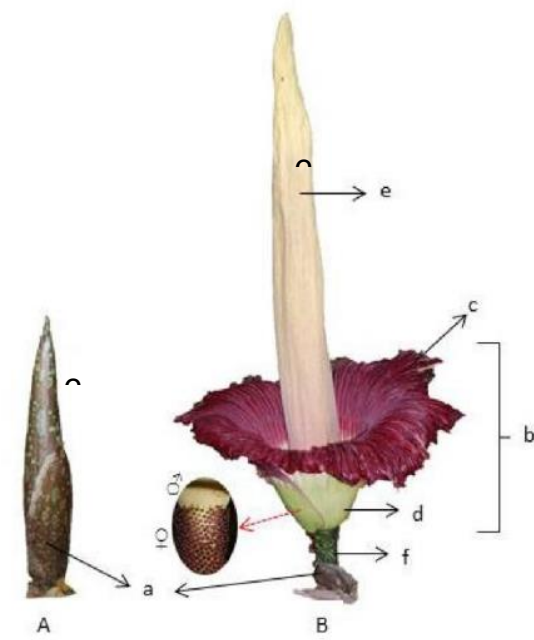

Inflorescence bud (A) and blooming flower (B) parts: cataphylls (a), spathe (b), limb (c) spathe (d), sterile spadix appendage (e1); inzet: male and female flowers are located at lower part of spadix (e2), and peduncle (f) (Gandawijaja et al., 1983; Graham and Hadiah, 2004; Lobin et al., 2007; Li, 2013)
Perbungaan pada bunga bangkai merupakan sekelompok bunga kecil jantan dan betina yang tersusun dalam bentuk bulir yang menempel pada tongkol. Tempat menempelnya bunga ada di bagian dasar tongkol. Tongkol (spadiks) berwarna kuning dan dikelilingi oleh seludang bunga yang berwarna merah keunguan. Tinggi spadiks dapat mencapai $3 \mathrm{~m}$ sehingga menjadikan bunga bangkai dijuluki "Bunga Raksasa". Bunganya berumah satu,

namun, bunga jantan dan bunga betina tidak masak bersamaan. Bunga mekar sempurna (bunga betina masak) di malam hari dan mengeluarkan bau bangkai. Bunga jantan masak keesokan harinya menghasilkan serbuk sari berwarna kuning, sehingga secara alami sulit menyerbuk sendiri. Ketika penyerbukan bunga bangkai tak terjadi, bunga itu akan layu seperti mati. Bunga dan tangkainya membusuk seperti tak membekas. Bunga bangkai itu tidak mati, namun memasuki masa istirahat atau dorman. Selanjutnya tumbuh menjadi fase bunga. Hal unik dari tanaman ini terdapat dua fase hidup yaitu generative (berupa bunga) dan vegetative (berupa daun) yang tidak dapat dilihat bersamaan dalam satu tumbuhan. Jadi saat 
berwujud daun tidak akan berbunga dan ketika tiba waktu berbunga tidak memiliki daun.

Buah berwarna merah cerah atau orange tua dan menggerombol. Jika dipetik satu buahnya, maka akan terlihat bentuk buahnya yang lonjong agak membulat dengan ujung yang meruncing dengan warna kehitaman. Menurut peneliti asal University of Wisconsin, AS, Thomas C

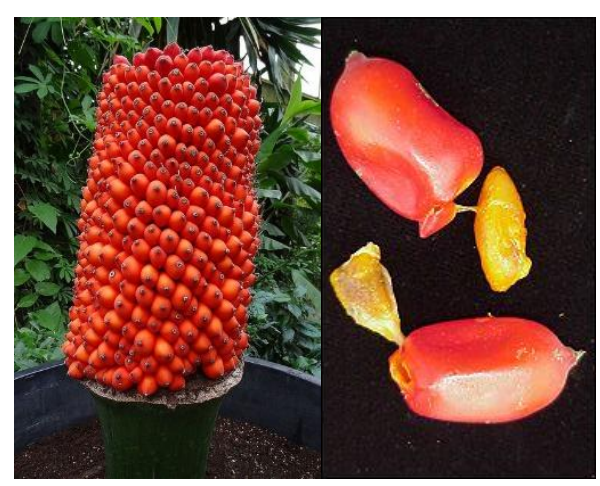
Gibson, di benua Eropa dan Amerika saja, ada sekitar 6.000 kebun raya dan arboretum yang mengoleksi bunga bangkai raksasa biji berwarna merah, sebutir biji bunga bangkai membutuhkan waktu 20-40 thn untuk berbunga. Sedangkan menurut Yuzzami (2009), buah pada tanaman ini memiliki satu biji karena termasuk buah buni. Biji akan berwarna jingga-merah, jarang yang berwarna biruputih. Bijinya berbentuk ellipsoid.

Amorphophallus titanum (Becc.) dimanfaatkan sebagai tanaman hias karena bentuknya yang unik dan mampu menarik perhatian banyak pengunjung. Selain itu juga sebagai bahan penelitian bagi ilmuan-ilmuan di dunia. Manfaat lain yang dapai diambil dari tanaman ini adalah penggunaan umbinya sebagai bahan pangan. Namun, dalam pengolaanya memerlukan waktu yang lama sebab umbi memiliki getah yang menjadikan gatal. Umbinya bermanfaat karena kandungan Glucomannan-nya. Glucomannan memiliki kegunaan sebagai zat pengental, jelly yang kaya serat (dietaryfibers) dan dietary supplements (untuk antikolesterol, penetralisir kadar gula darah, kesehatan pencernaan, penyerapan zat beracun dalam pencernaan dan agen control berat badan) (Latifahetal.,2015).

\section{Kesimpulan}

Amorphophallus titanum merupakan tanaman endemik Pulau Sumatra yang memiliki ukuran besar sehingga sering disebut dengan bunga bangkai raksasa. Hal unik dari tanaman ini terdapat dua fase hidup yaitu generative (berupa bunga) dan vegetative (berupa daun) yang tidak dapat dilihat bersamaan dalam satu tumbuhan. Jadi saat berwujud daun tidak akan berbunga dan ketika tiba waktu berbunga tidak 
memiliki daun. Amorphophalus titanum tersebar di seluruh hutan-hutan Sumatra sebagai tumbuhan bawah kanopi (undergrowth) pada tanah berkapur. Akar pada Amorphophallus titanum berupa umbi. Umbi berbentuk membulat agak gepeng. Batang yang dimiliki oleh Amorphophallus titanium merupakan batang semu yang tersusun oleh pelepah daun yang saling berlekatan. Helaian daun dengan diameter sekitar $7 \mathrm{~m}$, pinak daun berbentuk elips melanset, panjang mencapai $40 \mathrm{~cm}$, ujung meruncing. Perbungaan pada bunga bangkai merupakan sekelompok bunga kecil jantan dan betina yang tersusun dalam bentuk bulir yang menempel pada tongkol. Buah berwarna merah cerah atau orange tua dan menggerombol. Biji berwarna jingga sampai merah. Amorphophallus titanum dimanfaatkan sebagai tanaman hias dan bahan penelitian, sedangkan umbinya sebagai pengental jelly.

\section{Daftar Pustaka}

Hetterscheid, W. L. A. \& S. Ittenbach. (1996). Everything you always wanted to know about Amorphophallus, but were afraid to stick your nose into. Aroideana. Vol 19 : 7-131

Latifah, D dan Purwantoro, R.S. (2015). Perkecambahan Biji Bunga Raksasa Amorphophallus titanum. Warta Kebun Raya, 13(1)

Latifah, D dan Purwantoro, R.S. (2015). SEED GERMINATION OF THE CORPSE GIANT FLOWER Amorphophallus titanum (Becc.) Becc. Ex Arcang: THE INFLUENCE OF TESTA.Berita biologi.14(1):39-48

Latifah, D., Wawangningrum, H., Hartini, S., \& Munawaroh, E. (2015). HOW TO PREDICT THE BLOOMING OF THE GIANT CORPSE INFLORESCENCE Amorphophallus titanum (Becc.) Becc. ex Arcang [Prediksi Mekarnya Bunga Bangkai Raksasa Amorphophallus titanum (Becc.) Becc. ex Arcang]. Berita Biologi, 14(2), 111-120.

Lobin,W, et.al. (2007). The Cultivation of Titan Arum (Amorphophalus titanum) a Flagship Species For Botanic Gardens. The Journal of Botanic Garden Horticulture, No.5

Mogea, J. P., D. Gandawidjaja, H. Wiriadinata, R.E. Nasution, \& Irawati. (2001). Tumbuhan Langka Indonesia. Bogor: Herbarium Bogoriense P3 BiologiLIPI. 
Munawaroh, Esti dan Yuzammi, J. R. (2017). Peta Persebaran Populasi Amorphophallus titanum (Becc.) Becc. ex Arcang di Lampung, Sumatra : Upaya Menuju Proposal ke IUCN Red Data List dan Konservasi Ex Situ. Buletin Kebun Raya. Vol 20 (2) : 119-129

Poerba, Y, S dan Yuzammi. (2008). Pendugaan Keragaman Genetik Amophophalus titanum Becc. Berdasarkan Marka Random Amplified Polymorphic DNA. Biodiversitas, 9(2): 103-107

Yuzammi, J. R., dkk. (2015) Strategi dan Rencana Aksi Konservasi Bunga Bangkai (Amorphophallus titanum). Direktorat Jenderal Konservasi Sumber Daya Alam dan Ekosistem Kementerian Lingkungan Hidup dan Kehutanan RI

Yuzammi, J.R. Witono and W.L.A. Hetterscheid. (2014). Conservation status of Amorphophallus discophorus Backer \& Alderw. (Araceae) in Jawa, Indonesia. Reindwartia. Vol 14 (1) : 27 